\title{
Erratum to: An Investigation into the Use of Intelligent Systems for Currency Trading
}

\author{
Hannah Thinyane · Jonathan Millin
}

\section{Erratum to: Comput Econ (2011) 37:363-374}

DOI 10.1007/s10614-011-9260-4

The authors of this work would like to acknowledge the contribution made by Michael Winn.

\section{Acknowledgement}

We would like to thank Michael Winn for his help in understanding the Economics and Econometrics behind the system discussed in this article.

The online version of the original article can be found under doi:10.1007/s10614-011-9260-4.

H. Thinyane $(\varangle) \cdot$ J. Millin

Computer Science Department, Rhodes University, Grahamstown, South Africa

e-mail: h.thinyane@ru.ac.za

J. Millin

e-mail: jonomillin@gmail.com 